\title{
The Role of Perceived Managerial Discretion on Strategy Implementation and Its Implications on Organizational Performance: A Conceptual Model
}

\author{
Wilsa Theodore ${ }^{1 *}$, Rhenald Kasali ${ }^{1}$, T. Ezni Balqiah ${ }^{1}$, Lily Sudhartio ${ }^{1}$ \\ ${ }^{1}$ Department of Management, Faculty of Economics and Business, Universitas Indonesia \\ E-mail: wilsa.theodore@ui.ac.id
}

\begin{abstract}
The rapidly changing and disruptive environment makes the business competition more hypercompetitive. The fundamental challenge that companies often face is not in the strategic planning process, but rather on how to ensure the formulated strategy can be well-implemented. Currently, the literature is still dominated by theories and practical advice on planning and strategy formulation, and there is only limited studies on the role of discretion on strategy implementation. Therefore, this study aimed to find out what is the role of perceived managerial discretion in the process of strategy implementation and its implications on organization performance. By reviewing the literatures, this study examined whether task environment, organizational agility and cognitive complexity influence the managerial discretion, and whether strategy implementation mediates perceived discretion of middle manager and organization performance. This paper presented a proposed research model, four propositions that need to empirically be tested, proposed research method, and a conclusion.
\end{abstract}

Type of paper: Review

Keywords: perceived managerial discretion; discretion; strategy implementation

\section{Introduction}

The ability to implement strategies can served as a company's competitive advantage, where business competition is increasing and business uniqueness are challenging to find (Barney \& Zajac, 1994; Bossidy \& Charan, 2011; Noble, 1999). However, research on formulation issues gets more attention than the implementation issues (Hutzschenreuter \& Kleindienst, 2006). One potential cause of this is some strategy makers think that the single element to achieve success is through strategy formulation (Noble, 1999). In addition, the content of the strategy and how the relationship between strategy and performance is more frequently researched than the strategy process itself (Hafsi \& Thomas, 2005).

O'Reilly et al. (2010) and Wangrow, Schepker, \& Barker (2014) stated that to be able to implement strategy effectively, it requires continuous communication and discretion at all levels of the organization. A person is said to have discretion when he knows what options he has for 
acting that is acceptable to important stakeholders, through his insight and political intelligence (Hambrick \& Finkelstein, 1987). Managerial discretion stresses the constraints, on which discretion to act is inside the "zone of acceptance" of the more controlling parties, especially those who control critical resources and contingencies. While during strategy implementation process, managers in organizations need resources and contingencies managed by others that may influence the success of strategy implementation.

A review of literatures by Wangrow et al. (2014) indicate that managerial discretion plays a role in organizational outcomes such as the diversity of organizational performance, commitment to predetermined activities or even compensation of the chief executive. Moreover, studies related to strategy implementation and change management indicate that middle managers have important role in explaining change and ensuring strategy is well implemented. Managers that fail to be given discretion will constrain their ability in executing strategies without asking for approval and limiting the speed of implementing strategies. However, empirical studies examining the discretion level perceived by middle managers in an organization remain limited and place more emphasis on the context that determines managerial discretion (Hutzschenreuter \& Kleindienst, 2013; J. Li \& Tang, 2010; Wangrow, Schepker, \& Barker, 2014). Thus, this study will examine the role of middle managers and their perceived discretion during strategy implementation.

In the healthcare industry, managerial discretion is limited by task environment factor such as the regulated environment (Hambrick \& Abrahamson, 1995; Hambrick \& Finkelstein, 1987; Peteraf \& Reed, 2007). When the environment is characterized with ambiguity, complexity and asymmetric information and the managers' discretions are restricted in one area, then they will use their discretion in different area to adjust to those (Hambrick, 1989; Peteraf \& Reed, 2007). By this adaptive mechanism, they exercise their discretion in administrative process by making some modifications or intangible factors that are affected indirectly by the regulations.

Similar to other countries, healthcare industry in Indonesia also experiences this dynamic regulatory environment (Frost \& Sullivan, 2016). The implementation of universal healthcare coverage or Jaminan Kesehatan Nasional (JKN) in 2014 and Investment and Economy Policy Package (Paket Ekonomi) number 11 in 2016 that emphasize on increasing health services and affordable healthcare products to support JKN are some examples of changes in regulation and government policy. Withmorethan 200 pharmaceutical companies, 95 medical device companies and more than $12 \%$ annual growth rate, Indonesian healthcare market is very competitive, fragmented and growing (Paket Ekonomi 11, 2016). Combining dynamic regulatory condition and the characteristics of the industry, healthcare provides opportunities to learn more about how discretion perceived by managers impact their behavior during implementation phase of strategy and organization performance. Research in healthcare market can indirectly support Indonesian government program of Healthy Indonesia or Indonesia Sehat.

This paper examined whether managerial discretion perceived by middle manager is affected by three antecedents namely, task environment, organizational agility and manager's cognitive complexity, which latter affects the strategy implementation and moreover, the organization performance. After the introduction, this paper presents the literature review. The following section proposed research model with four propositions, proposed methodology, and conclusion. 


\section{Literature Review}

\section{$2.1 \quad$ Strategy Implementation}

The widely-used approach in general management categorizes activities into strategy formulation and strategy implementation. Initially, general management or top management formulates a strategy, using rational process, and then constructs the structure and management processes of an organization to ensure the expected behavior (Ansoff, 1965, Learned et al., 1969; Hofer and Schendel, 1978; Lorange and Vancil, 1977 in Guth \& MacMillan, 1986). However, this approach ignores the constraints faced to gain organizational commitment in executing strategy.

In the words of Li, Sun, \& Eppler (2010), the definition of strategy implementation is grouped into three perspectives, namely process perspective, behavior perspective and hybrid perspective. In the hybrid perspective, Wheelen \& Hunger (2012) define the strategy implementation as a merger of the activities and options required to execute strategic plans. Implementation of strategy is a process whereby objectives, strategies and policies are realized through the development of programs, budgets and procedures. Wheelen \& Hunger (2012) state that strategy formulation and strategy implementation are two sides of the same coin.

Bonoma and Crittenden (1998) cited by Crittenden \& Crittenden (2008) convey that the implementation consists of two main variables: managerial skills and structure. The structure provides a framework or configuration in which the company can operate effectively, whereas managerial skills are behavior-related activities where managers engage in structures developed by the organization. In short, according to Bonoma \& Crittenden (1988), strategies are implemented through structures, with managerial skills as key indicators that determine the success or failure of the implementation effort.

\subsection{Middle Management and Strategy Implementation}

The formulation and implementation of strategies that should be interdependent are carried out by two different groups of managers, in which top management does the formulation and middle management does the implementation (Hrebiniak, 2006). This separation of responsibilities is suspected to be one of the most frequent causes of difficulties in translating formulated strategies into activities, where the operational managers or middle managers are usually under pressure to show results immediately.

Middle managers who feel that their interests are disturbed or may face dysfunctional role conflict can redirect the strategy, delay in implementation or reduce implementation quality, and sabotage strategies (Guth \& MacMillan, 1986; Wooldridge, Schmid, \& Floyd, 2008). Pressure to show immediate results and minimal support to middle management can affect the attitudes and commitments of these managers and this demonstrate the importance of middle managers in determining the success of strategy implementation.

Strategy implementation is measured by four dimensions. The first dimension is diffusing information which is defined as how middle managers provide staff with updated information and provide top management with organization's status and needs (Birken, Lee, $\&$ Weiner, 2012). The second dimension is synthesizing information, which is defined 
as when middle managers engaged in integrating and interpreting information activities, including collecting and summarizing relevant issues and then forward it to superiors and other employees (Birken et al., 2012; Floyd \& Wooldridge, 1992; Mantere, 2008). Next, the third dimension is mediating which is defined as bridging between strategy and daily activities. Finally, the fourth dimension is selling, which is defined as conveying to others in organization on the importance of a strategy to be implemented (Birken et al., 2012; Uyterhoeven, 1989)

\subsection{Perceived ManagerialDiscretion}

Managerial discretion in this study is based primarily on the seminal concepts of Hambrick \& Finkelstein (1987), namely the latitude of action a manager has that affects organizational outcomes. Discretion is different from choice or action, but it emphasizes freedom of action. Whichever option is available that an individual chooses and the effect of that choice is a consequence of discretion, and not part of the discretion (Caza, 2012). Therefore, managerial discretion or discretion is the flexibility that managers must manage in the most appropriate way (Caza, 2011; Hambrick \& Finkelstein, 1987).

Discretion determines the action and is influenced by three forces namely the task environment, internal organization factor, and managerial characteristics (Hambrick \& Finkelstein, 1987). External environmental factors are industrial structure, industrial growth rate, number of competitors, level of political or regulatory barriers and product differentiation levels. Meanwhile, factors affecting organizational characteristics are organizational size, age, resource availability, culture and patterns of relation among employees. Factors on manager's characteristics are interpersonal skills, tolerance to ambiguity, commitment and strategic outcomes, aspiration levels and confidence levels. The flexibility to act in a specific condition depends on everyone, regardless of functional position, rank or function, although the degree and domain of discretion may differ among individuals. Furthermore, managerial discretion is also influenced by the perception on flexibility of the person or perceived managerial discretion, and is not only influenced by objective managerial discretion derived from formal organizational structures (Carpenter \& Golden, 1997; Caza, 2011).

Related to tactics used to influence the success of strategy implementation, Ahearne, Lam, \& Kraus (2014) show that social capital owned by middle management influences organizational performance. The social capital of the reputation can increase the influence of middle managers to upward levels while the social capital of information can increase the impact of their performance on downward influence. The ability of middle management to influence the upper and lower levels in the strategy implementation process is suspected relate to managerial discretion. Higher discretion provides leaders with greater choice and greater freedom (Campbell, Campbell, Sirmon, Bierman, \& Tuggle, 2012; Hambrick \& Abrahamson, 1995; Wangrow et al., 2014). Based on discretion analysis within the organization, Caza (2012) identifies eight discretion domains by combining the results of the literature review, qualitative meta-synthesis and content analysis. Of the eight domains of discretion associated with the implementation of strategies that are diffusing, synthesizing, mediating, and selling, the managerial discretion to be examined in this study are three discretion, they are technical, staffing and support. These three discretions refer to the discretion profile at the managerial level proposed by Caza (2012). 


\subsection{Task Environment}

Environment has major effects on management, including corporate strategy, structure, processes and outcomes (Goll \& Rasheed, 1997). Organizations work effectively when there is a fit between the products or services they offer with the targeted market. Market demand will change as the industry grows. The dimensions for measuring organizational task environments vary greatly, but there is consensus among researchers regarding important dimensions (Dess \& Beard, 1984). Based on the dimensions proposed by Aldrich, Jurkovich, Pfeffer and Salancik, Mintzberg and Scott, there are three dimensions like the important environmental conditions identified by Child in 1972. Dess \& Beard (1984) states that the three dimensions of environmental uncertainty is munificence, dynamism and complexity

Munificence is the availability (or scarcity) of the important and specific resources that a company needs to operate in its environment (Castrogiovanni, 1991). High availability shows that the market targeted by the company has a lot of or is rich with capital for investment, and many economic development programs that allow the business or industry community to grow. Dynamism or environmental dynamics are environmental uncertainties caused by unpredictable changes and result in increased uncertainty towards members of the organization (Dess \& Beard, 1984). Complexity is the environmental uncertainty caused by the variety of environmental elements (Dess \& Beard, 1984).

\subsection{Organizational Agility}

The rapidly changing environmental conditions certainly affect the organization to change as well. Hambrick and Finkelstein (1987) argue that with the increasing strength of inertia, the discretion of a leader becomes lower. In line with that, Williams, Worley \& Lawler (2013) argue that firms that generate greater profits than their competitors consistently have one common characteristic of a highly-developed capacity to adapt their business to change. Organizational agility enables organizations to respond effectively, timely, and sustainably as environmental conditions change. Furthermore, Williams et al. (2013) states that this agility is dynamic capability, that can see the potential opportunities and threats, solve problems and change the resource base owned by the company. Agile organizations often change, and they change for the sake of gaining competitive advantage, and not just change for the sake of change. Managing an agile company requires four sets of different but complementary activities. Williams et al. (2013) found that there is a correlation between a well-performed firm with firms that have high scores on three or four of these agility routines.

The four regular activities related to the agility of this organization are as follows. Agile companies could strategize in dynamic way or strategizing, the ability to see changes in the external environment or perceiving, the ability to test possible reactions or testing and the ability to implement change or implementing on the product, technology, structure, system and overall capability. The ability to manage the whole system as a harmonious routine is what distinguishes a superior organization from its competitors (Williams et al., 2013).

\subsection{Cognitive Complexity}

To deal with disruptions and discontinuities nowadays, not only are organizations required to be agile, but also human beings who are the components that make up the organization need to 
be more agile and strategic leadership is needed even more (Boal \& Hooijberg, 2001).

In the perspective of neo contingency it is explained that the way organizations respond to the environment depends on the leaders or decision makers of the organization (Donaldson, 2001). Thus, the characteristics of the leader can have a major influence on the survival and performance of the organization.

The ability of an organization to be adaptive to change requires leaders with cognitive complexity and behavioral flexibility to identify and react to the paradox, the contradiction or complexity that implies changes (Boal \& Hooijberg, 2001; Hooijberg, 1996; Hooijberg, Hunt, \& Dodge, 1997). Hambrick (1989) argues that strategic leadership occurs when the environment is affected by ambiguity, complexity, and information overload.

The basic premise of cognitive complexity is that individuals who have complex cognitions process information differently and perform tasks better, because they use more categories or dimensions to differentiate the stimuli and can see more similarities between categories or dimensions (Hooijberg et al., 1997). This is in line with a cognitive perspective in strategic management science where strategic cognition is the link between cognitive structure and decision-making processes in formulation and strategy implementation (Porac \& Thomas, 2002). So, a leader with a complex cognitive system will have greater discretion needed when making strategic decisions in the strategy implementation phase.

There are two dimensions to measure cognitive complexity namely differentiation and integration (Cursue, 2008). Cognitive complexity is the result of those two interrelated cognitive processes. Differentiation is defined as the number of aspects of the system. Integration is defined as the level and nature of foundation used to integrate aspects of the system (Calori, Johnson, \& Sarnin, 1994; Iederan, Curseu, \& Vermeulen, 2009)

\section{Proposed Research Model and Propositions}

The task environment will affect managerial discretion. The environment is influenced by the factors in which the organization is in the industry and how the organization functions in that domain. The environment is predicted to affect managerial discretion positively when there are different products or services in the industry, the market for a product or service is growing and the demand for products or services fluctuates (Boyd \& Gove, 2006; Dess \& Beard, 1984; Hambrick \& Finkelstein, 1987). An environment in which the availability of resources is munificent and can support organizational growth will have a negative effect on perceived managerial discretion. Thus, an environment with limited resources is predicted to have a positive effect on perceived managerial discretion.

Furthermore, a dynamic environment that exhibits a volatile or unpredictable environment will have a positive effect on perceived managerial discretion (Boyd \& Gove, 2006; Dess \& Beard, 1984. The complexity in the environment is the diversity in the industry, for example the concentration of inputs or the density of the organization (Boyd \& Gove, 2006; Dess \& Beard, 1984). Complexity is positively associated with uncertainty and complexity is predicted to have a positive effect on perceived managerial discretion. Thus, industries with the character of resource limitations, dynamic and complex will have a positive influence on perceived managerial discretion. 
Proposition 1: Task Environment has positive influence toward Perceived Managerial Discretion

Williams et al. (2013) state that organizational agility enables organizations to respond effectively, timely, and sustainably as environmental conditions change. Agile organizations often change, and they change for the sake of gaining competitive advantage, and not just for the sake of change. There is a correlation between firms that perform well with companies that have high scores on three or four of these agility routines (Williams et al., 2013). Four routine activities related to the agility of this organization are as follows (1) ability to strategize in dynamic way or strategizing, (2) ability to perceive changes in the external environment (perceive environmental change or perceiving), (3) the ability to test the possible reactions (test possible response or testing) and (4) the ability to implement change (implementation change or implementing) on the product, technology, structure, system and overall capability. Hambrick \& Finkelstein (1987) argue that the internal organization determines the level of acceptability of the organization to various actions and will further affect the flexibility of leaders to determine the course of action.

Proposition 2: Organizational Agility has positive influence toward Perceived Managerial Discretion

Hambrick \& Finkelstein (1987) argue that managerial discretion is limited to some extent by the ability of managers to see options and simultaneously process information based on opposite alternatives. Hambrick \& Finkelstein concluded that managers with more complex cognitive systems would have greater discretion when making strategic decisions because they realized more choices and were able to distinguish more dimensions. So, a leader with a complex cognitive system will have greater discretion needed when making strategic decisions in the strategy implementation phase. According to Cursue (2008), cognitive complexity is the result of two interrelated cognitive processes, namely differentiation and integration.

Proposition 3: Cognitive Complexity has positive influence toward Perceived Managerial Discretion

Middle managers play an important and strategic role in thinking and implementing organizational strategy (Floyd \& Woolridge, 1992; Hutzschenreuter \& Kleindienst, 2006; Rensburg, Davis, \& Venter, 2014). Birken, Lee, \& Weiner (2012) mentioned that in their role to close the structural gap in health organizations, middle managers can bridge the limitations of information that employees need to be able to implement health innovations by doing: diffusing information, synthesizing information, mediate between strategy and day-to-day activities and sell implementation. To fully implement the strategy, the middle management needs to have the flexibility to act greatly where the uncertainty factor can arise during the implementation process.

Proposition 4: Strategy Implementation mediates the influence of Perceived Managerial Discretion positively to Unit Performance

Based on the above explanation the proposed research model as follows: 


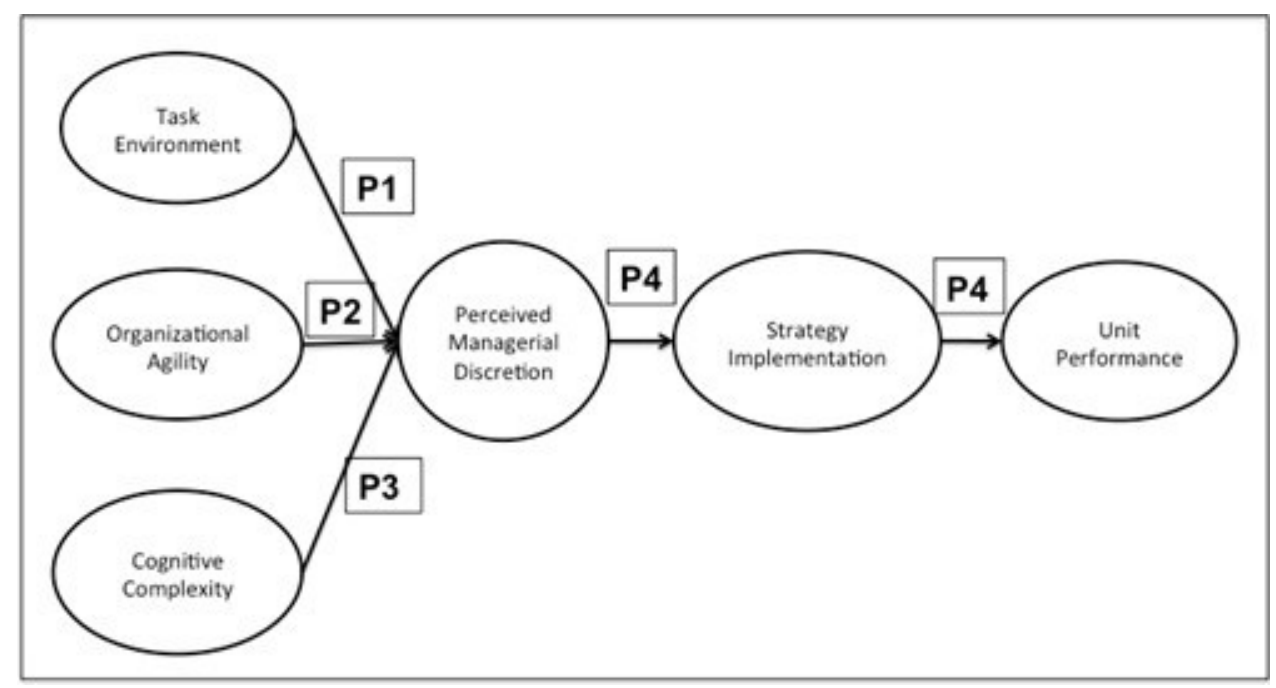

Figure 1. Research Model

\section{Research Method}

This study involved research on articles in the leading management journals and books. Some keywords used to find these articles are "strategy implementation", "managerial discretion", "task environment", "organizational agility", and "cognitive complexity". Some of management journals database used are ProQuest, JSTOR, Science Direct, and archive of Academy of Management Journal.

The empirical study needs to be done to the test the model. Thus, the proposed design of the empirical study is Explanatory Sequential Mixed Methods Design that uses qualitative data to clarify the results of quantitative methods, to obtain a more in-depth understanding of the research question (Molina-Azorin, 2012; Creswell, 2014). Although using mixed methods, this study is more dominant on the quantitative research tailored to research objectives and research questions. The questionnaire will be developed and adapted from several previous studies. The measurement of task environment will be adapted from the measurement developed by Dess \& Beard (1984) and Boyd \& Gove (2006). Organizational agility measurement will be developed and adapted from the questionnaire developed by Williams et al. (2013) and Worley et al. (2016). For cognitive complexity, this study referred to the study conducted by Bieri (1961), Hitt \& Tyler (1991), and Curseu \& Rus (2005). As the measurement for perceived managerial discretion, this study will adopt and adapt research from Hambrick \& Finkelstein (1987) and Caza (2012) Strategy implementation measurement will be developed with reference of Cater \& Pucko (2010) and Birken, Lee, \& Weiner (2012).

The data to be obtained is the perception of middle managers that hold strategic position, since middle managers have dual role of translating strategy into implementable action and make decision daily. The data collected from respondents of this study will be based on purposive sampling of middle managers in a national healthcare company in Indonesia. The data will be collected through survey and focus group discussion. The analysis of the data obtained from this study will be done using Structural Equation Modeling (SEM) 


\section{Conclusion}

After literature review and development of research propositions, this paper presented a conceptual model which links perceived managerial discretion and strategy implementation. The model consists of six constructs to close a research gap on the factors affecting managerial discretion perceived by middle managers and if strategy implementation mediates between perceived discretion and organization performance. Thus, the model is the base in building the four propositions that need to be tested empirically using the mixed method design. The study is expected to give insights to leaders in the healthcare companies in Indonesia to ensure formulated strategy gets executed and in return, support the government program of Healthy Indonesia or Indonesia Sehat.

\section{References}

Birken, S. A., Lee, S.-Y. D., \& Weiner, B. J. (2012). Uncovering Middle Managers' Role in Healthcare Innovation Implementation. Implementation Science, 7(1), 28. http://doi. org/10.1186/1748-5908-7-28

Bonoma, T. V., \& Crittenden, V. L. (1988). Managing Marketing Implementation. Sloan Management Review, 29(7), 7-14.

Bossidy, L., \& Charan, R. (2011). Execution - The Discipline of Getting Things Done. Random House Business Books.

Boyd, B. K., \& Gove, S. (2006). Managerial Constraint: The Intersection Between Organizational Task Environment and Discretion. In Research Methodology in Strategy and Management (Vol. 3, pp. 57-95). http://doi.org/10.1016/S1479-8387(06)03005-0

Calori, R., Johnson, G., \& Sarnin, P. (1994). CEOs` Cognitive Maps and the Scope of the Organization. Strategic Management Journal, 15, 437-457.

Cater, T., \& Pucko, D. (2010). Factors of Effective Strategy Implementation. Journal for East European Management Studies, (3), 207-237.

Caza, A. (2012). Typology of the eight domains of discretion in organizations. Journal of Management Studies, 49(1), 144-177. http://doi.org/10.1111/j.1467-6486.2010.00982.x

Crittenden, V. L., \& Crittenden, W. F. (2008). Building a capable organization: The eight levers of strategy implementation. Business Horizons, 51(4), 301-309. http://doi.org/10.1016/j. bushor.2008.02.003

Dess, G. G., \& Beard, D. W. (1984). Dimensions of Organizational Task Environments. Administrative Science Quarterly, 29(1), 52-73.

Floyd, S. W., \& Wooldridge, B. (1992). Managing Strategic Consensus: The Foundation of Effective Implementation. Academy of Management Executive, 6(4), 27-39. http://doi. org/10.5465/AME.1992.4274459 
Floyd, S. W., \& Woolridge, B. (1992). Middle management involvement in strategy and its association with strategic type: A research note. Strategic Management Journal, 13, 153-167. http://doi.org/10.1016/0024-6301(93)90287-P

Frost \& Sullivan. (2016). Indonesia Healthcare Outlook: Value Proposition and Market Entry Guides for Indian Investors.

Guth, W. D., \& MacMillan, I. C. (1986). Strategy Implementation Versus Middle Management Self-Interest. Strategic Management Journal, 7(4), 313-327. http://doi.org/10.1002/ smj.4250070403

Hafsi, T., \& Thomas, H. (2005). The field of strategy: In search of a walking stick. European Management Journal, 23(5), 507-519. http://doi.org/10.1016/j.emj.2005.09.006

Hambrick, D. C. (1989). Putting Top Managers Back in the Strategy Picture. Strategic Management Journal, 10, 5-15. http://doi.org/10.1002/smj.4250100703

Hambrick, D. C., \& Abrahamson, E. (1995). Assessing Managerial Discretion Across Industries: A Multimethod Approach. Academy of Management Journal, 38(5), 1427-1441.

Hambrick, D. C., \& Finkelstein, S. (1987). Managerial Discretion: A Bridge Between Polar Views of Organizational Outcomes. Research in Organizational Behavior, 9, 369-406.

Hrebiniak, L. G. (2006). Obstacles to effective strategy implementation. Organizational Dynamics, 35(1), 12-31. http://doi.org/10.1016/j.orgdyn.2005.12.001

Hutzschenreuter, T., \& Kleindienst, I. (2006). Strategy-Process Research: What Have We Learned and What Is Still to Be Explored. Journal of Management, 32(5), 673-720. http://doi.org/10.1177/0149206306291485

Hutzschenreuter, T., \& Kleindienst, I. (2013). (How) Does discretion change over time? A contribution toward a dynamic view of managerial discretion. Scandinavian Journal of Management, 29(3), 264-281. http://doi.org/10.1016/j. scaman.2012.11.009

Iederan, Q. C., Curseu, P. L., \& Vermeulen, P. (2009). Effective Decision-Making: The Role of Cognitive Complexity in Strategic Decisions. Studia Psychologica, 51(4), 293-304.

Li, J., \& Tang, Y. (2010). Ceo Hubris and Firm Risk Taking in China: the Moderating Role of Managerial Discretion. Academy of Management Journal, 53(1), 45-68.

Li, Y., Sun, G., \& Eppler, M. J. (2010). Making Strategy Work: A Literature Review on the Factors Influencing Strategy Implementation. Handbook of Research on Strategy Process. http://doi.org/10.4337/9781849807289

Mantere, S. (2008). Role Expectations and Middle Manager Strategic Agency. Journal of Management Studies, 45(2), 294-316. http://doi.org/10.1111/j.1467-6486.2007.00744.x 
Peteraf, M. A., \& Reed, R. (2007). Managerial Discretion and Internal Alignment under Regulatory Constraints and Change. Strategic Management Journal, 28, 1089-1112. http://doi.org/10.1002/smj

Qi, H. (2005). Strategy Implementation : The Impact of Demographic Characteristics on the Level of Support Received by Middle Managers. Management International Review, $45(1), 45-70$.

Rensburg, M. J. Van, Davis, A., \& Venter, P. (2014). Making Strategy Work: the Role of the Middle Manager. Journal of Management and Organization, 20(2), 165-186. http://doi. org/10.1017/jmo.2014.33

Uyterhoeven, H. (1989). General Managers in the Middle. Harvard Business Review, 67(5), $136-145$.

Wangrow, D. B., Schepker, D. J., \& Barker, V. L. (2014). Managerial Discretion: An Empirical Review and Focus on Future Research Directions. Journal of Management, 41(1), 99135. http://doi.org/10.1177/0149206314554214

Williams, T., Worley, C. G., \& Lawler, E. E. I. (2013). The Agility Factor. Strategy \& Business, 1-8.

Wooldridge, B., Schmid, T., \& Floyd, S. W. (2008). The Middle Management Perspective on Strategy Process: Contributions, Synthesis, and Future Research. Journal of Management. http://doi.org/10.1177/0149206308324326

Worley, C. G., Williams, T., \& Lawler, E. E. I. (2014). The Agility Factor: Building Adaptable Organizations for Superior Performance. Jossey-Bass. 